\title{
Extended Shopping Experiences in Hypermarket
}

\author{
Hasliza Hassan ${ }^{1} \&$ Muhammad Sabbir Rahman ${ }^{2}$ \\ ${ }^{1}$ Faculty of Business and Law, Multimedia University, Jalan Ayer Keroh Lama, Bukit Beruang, Malaysia \\ ${ }^{2}$ Graduate School of Management, Multimedia University, Jalan Multimedia, Cyberjaya, Malaysia \\ Correspondence: Hasliza Hassan, Faculty of Business and Law, Multimedia University, Jalan Ayer Keroh Lama, \\ 75450 Bukit Beruang, Melaka, Malaysia. E-mail: hasliza.hassan@mmu.edu.my; liza.hassan@yahoo.com
}

\author{
Received: April 22, 2012 Accepted: May 15, 2012 Online Published: August 17, 2012 \\ doi:10.5539/ass.v8n11p138 URL: http://dx.doi.org/10.5539/ass.v8n11p138
}

\begin{abstract}
Hypermarkets were introduced as a self-service concept for grocery retailing in which the service provided is very limited. In line with the transformation in hypermarket retailing, the service that is offered has been improvised to enhance the overall shopping experience. Nowadays, hypermarkets are not just a place to purchase basic essential groceries for the household but also as a place for shoppers to spend time together with family and friends. In general, the hypermarket retailing concept has been upgraded and is comparable to a shopping centre. This research focuses on shopper preferences towards the enhancement of hypermarket shopping experiences in five main service categories: 1) banking services, 2) children's playgrounds or indoor play-lands, 3) covered parking area, 4) food and beverage area, as well as 5) post office.
\end{abstract}

Keywords: experience, hypermarket, shopping

\section{Introducation}

Shopping activities are not just for the sake of fulfilling household necessities, but extend far beyond basic economic needs (Fiore and Kim, 2007; Sit, Merrilees and Birch, 2003). The study on shopping behaviour was first recognized through marketing scholars by Tauber in 1972 through the investigation of "why do people shop?". The finding of eleven motives for shopping proved that most of the motives are both pleasure and leisure driven (Millan and Howard, 2007). This finding is further supported by another finding in which shopping can be considered as a leisure activity (Mintel, 2000) and entertainment, especially among young adults (Howard, 2007). The behaviour of shoppers is more unpredictable today than it was in previous decades since shoppers tend to seek more variety. It is also influenced by the motive or what kind of items are being purchased. This research focuses on grocery shopping behaviour by looking at the shopper preferences in respect of the extended services offered by hypermarkets.

\section{Hypermarket Shoppers}

Although shoppers might have the same objective, their attitude towards shopping might differ (Ahmed, Ghingold and Dahari, 2007). Different researchers categorize shoppers differently. Stone (1954) categorized shoppers into four, which consists of: 1) economic shopper, 2) personalizing shopper, 3) ethical shopper and 4) apathetic shopper. Solomon (1994) added another additional category, which is: 5) recreational shopper. Boedeker (1995) simplified the categorizations into two categorizes which are: 1) new-type shoppers and 2) traditional shoppers. According to the recent findings by Sit et al. (2003), shoppers can be clustered into six categories, which are: 1) serious, 2) entertainment, 3) demanding, 4) convenience, 5) apathetic and 6) service shopper. All of these perceptions can be streamlined into two main groups of shoppers, which are: 1) utilitarian and 2) hedonistic. People in less developed economic societies will shop for utilitarian purposes while people in more developed economic societies will shop for hedonic purposes. Committed shoppers will shop for both utilitarian and hedonic purposes by spending an average of more than two hours for pre-planned shopping accompanied by someone else. The difference between the actual and expected shopping experience will affect the shopper's perception (Babin, Darden and Griffin, 1994; Millan and Howard, 2007).

\subsection{Extended Hypermarket Services}

Services have become part of the shopping environment (Sit et al., 2003). Knowledge in service is one of the 
current trends to compete in the market by creating value for shoppers (Bolton, Grewal and Levy, 2007). Services are able to give high return to the company instead of just focusing on the products (Bjurklo, Edvardsson and Gebauer, 2009) since it will enhance the level of shopper satisfaction (Martinez-Ruiz, Jimenez-Zarco and Cascio, 2011). Service has become a new competency, differentiation and added element in selling physical products (Bjurklo et al., 2009; Brown, Sichtmann and Musante, 2011) to gain competitive advantage (Roy, 2010). Modification or extension of service features from the original is known as service extension (Lee and Ulgado, 1993). Brand identity and fitness are important for services extension (Viot, 2011). The low cost and risk to extend existing services has motivated many hypermarket retailers to try this new innovated strategy. Service extension might be successful if the shoppers believe that the quality of the extended service is parallel to the core service (Lee and Ulgado, 1993). Service in hypermarkets is limited since the business operation is more on the self-service concept. Enhancement of the basic self-service concept in the overall shopping experience could assist the hypermarket to enhance revenue. Self-service technology (SST) is one of the ways to reduce overall operation costs in hypermarket retailing business. The perception of differentiation in service can be enhanced through corporate branding (Bolton et al., 2007).

Long-term shopper loyalty is developed through service (Swoboda, Haelsig, Morschett and Schramm-Klein, 2007). Hypermarkets need to turn shoppers into promiscuous shoppers. A key challenge is to create a one-to-one relationship atmosphere between the shopper and the store in order to: 1) fully utilize shoppers' time and 2) make it appear as the personalization is just for the particular shopper. By paying attention to this, hypermarkets are able to deliver a positive experience that motivates the shoppers to revisit the store (Soars, 2003). Competitiveness is developed based on overall service experience (Kumar, 2005). Good service will prevent failure and diversify strategies (Mishra, 2000). Strong service will assist to build a positive relationship with the shopper, enhance shopper loyalty and switching costs as well as generating a barrier for competitors (Bolton et al., 2007). There should be an effort to manage the service to ensure it could be successful (Mascarenhas, Kesavan and Bernacchi, 2004). The success of a new service depends on the direct participation of the shopper and participation by various categories of management teams and employees rather than participation from outside parties from other companies. This can be determined by 1) sales volume and 2) profitability (Martin, 1996). It is very difficult to evaluate service since it is intangible unless the shoppers experience it (Lee and Ulgado, 1993). Shoppers will evaluate services based on cues that could be observed while consuming a tangible product (Roy, 2010). One of the common ways to evaluate service quality is through a mystery shopper. A mystery shopper is a particular person who comes to shop at the store and gives a rating based on experience to monitor the business operation from a shopper's point of view (Guy, 2003).

\subsection{Shopper Preferences on Extended Hypermarket Services}

Although no one could have a total understanding of shoppers (Bristol, 2002), it is crucial to operate a business according to the knowledge of shoppers. However, this knowledge is concealed away by the shopper (Liao, Chen and $\mathrm{Wu}, 2008$ ). An actual experience will provide knowledge to the shoppers (Pecotich, Pressley and Roth, 1996). A person will process information based on the level of involvement (Sun, 2010). Most shoppers perceive themselves as highly involved with grocery retailing (Swoboda, Haelsig, Schramm-Klein and Morschett, 2009). There is a slight difference in the expectation of shoppers who shop for products and services. A shopper who shops for products emphasizes more on store quality and variety of merchandise while a shopper who shops for services emphasizes more on experience, such as the cleanliness of the washroom (Dennis, Marsland and Cockett, 2001). However, it is impossible to treat all shoppers homogeneously and the same shoppers' behaviour might change depending on the situation. Some of the problems, such as crowding, parking availability and store atmosphere require more time for the hypermarket to solve. However, shoppers may accept crowding and parking issues in seasonal periods especially on certain occasions without dissatisfaction (Stoltman, Morgan and Anglin, 1999).

Grocery shopping consists of responsibility, routine and low involvement behaviour (Clarke, Hallsworth, Jackson, Kervenoael, Aguila and Kirkup, 2004; Dholakia, 1999; Thomas and Garland, 2004). Time constraints might hinder people from shopping (Millan and Howard, 2007). Shopping for groceries is stressful, especially when it is difficult to get parking space, handling a shopping trolley, carrier bag, unable to reach high shelves, unavailable product, overpriced product, lack of budget, queuing for checkout, malfunctioning cash dispensing machines, having too much choice, promotional information, misbehaving children and even handling the products that are being purchased, such as broken eggs, heavy potatoes and spilled milk in the car (Aylott and Mitchell, 1999). However, support from family members will enhance the motivation to do the grocery shopping (Dholakia, 1999). Influential factors for shopping are according to accessibility, convenience, parking space, service, cleanliness, quality, product range, assortment, price as well as design, size and location of outlet. This is 
followed by leisure attractions and community benefits (Arnold and Luthra, 2000; Clarke et al., 2004; Howard, 2007; Kent, 2003; Kirkup, Kervenoael, Hallsworth, Clarke, Jackson and Aguila, 2004; Seiders and Tigert, 2000). Consumers also prefer to have a routine shopping experience that is simple and efficient in a convenient place (Salmon, Buzzell and Cort, 2000). Recreational shopping without advance planning can be enjoyable and tends to extend the shopping duration (Chetthamrongchai and Davies, 2000). This group of shoppers emphasize service, time spent with family and friends and prefer a nice location to shop. This group of shoppers also likes to dine-in and spend additional time for shopping than non-recreational shoppers (Boedeker, 1995). Thus, general knowledge in marketing, merchandising, technical support and quality control will assist to configure the buying decision (Burt, 2000).

Traditionally, most shoppers perceive grocery shopping as a necessary but less-pleasurable experience than other types of shopping that create leisure experience (Hart and Davies, 1996). Shopping experience includes pre-shopping, shopping, post-purchase and product disposal. This experience is based on the consciousness-emotion-value (C-E-V) that is being built based on the: 1) individual, 2) shopping environment, as well as 3) interaction between the individual and the shopping environment. Stimulus elements are able to enhance existing consumption experience through consumer's cognitive or consciousness and affective or emotional processes. The shopping experience is very valuable since the scope is not just about selecting products on shelves (Fiore and Kim, 2007) but also involves social activity (Dennis, Jayawardhena, Wright and King, 2007), pleasure (Clarke et al., 2004) and recreation (Ramus and Nielsen, 2005). Thus, the shopping environment should be enhanced with a variety of shopping provisions (Hare, 2003). Shoppers expect to have "retailtainment" (Howard, 2007), which is an association of entertainment while shopping. Retailtainment is able to provide differentiation positioning strategies to attract shoppers. There are a many entertainment elements that could be offered to the shoppers, such as special events, food and beverages, as well as a safe and attractive shopping environment. The food and beverages that are being offered in cafés, food courts or restaurants motivate the shoppers to extend the shopping duration by having short breaks during shopping (Howard, 1993; Sit et al., 2003). Pleasure seeking shoppers usually enjoy shopping and prefer to have break-time with light food and beverages while shopping (Millan and Howard, 2007). Usually, this type of shopper will spend more money than shoppers who do not pause for a break (Howard, 1993). One of the strategies to cater for this leisure activity (Howard, 2007) is by having sub-retailers that will improve the overall value of shopping (Hutchison, Adair and McWilliam, 2008; Kaufman, 1996).

Leisure shopping is a subset of leisure retailing. The perception of leisure shopping depends on the characteristics of individual, objectives, social and nature of location (Howard, 2007). Malaysians tend to shop for pleasure and leisure, with 49 per cent of the Malaysian population spending their leisure time window shopping at shopping centres (Lee, 1995). In general, Malaysian shoppers will visit six sub-retailer outlets per trip (Ahmed et al., 2007) whereas American shoppers only visit five sub-retailer outlets per trip (Bloch, Ridgway and Dawson, 1994). Thus, there is a good opportunity to expand the size of the main store by having more sub-retailers. Renting out sites or spaces to the sub-retailers could assist in providing financial stability or income to the main retailer. The focus of product variety or perhaps sub-retailers should be based on location and lifestyle in a particular place (Salmon et al., 2000). However, shoppers perceive the meaning and importance of shopping differently. A pleasant store atmosphere and friendly personnel will enhance the pleasure of the consumers shopping experience (Wagner, 2007).

\subsection{The Scope of Extended Hypermarket Services}

Asian shoppers prefer to have a social environment setting in the grocery stores (Shannon and Mandhachitara, 2008). Parallel to this, due to urban lifestyle pressure, shoppers will always look for convenience where everything can be done at one particular place with minimum hassle. Consequently, this research investigates the shopper preferences on five main extended services that are provided by hypermarket retailers, which are: 1) banking services, 2) children's playground or indoor play-land, 3) covered parking area, 4) food and beverage area and 5) post office. These extended services are chosen since they represent the most consumable services by most Malaysians. Banking services include automatic teller machines (ATM), automatic cash or cheque deposit and bank branch or kiosk. Shoppers can drop by at the post office to deliver letters or packages, pay utility bills and renew road tax. For those shoppers who have children, a playground or indoor play-land may become an attraction to spend time together with family members. A covered parking area is highly suitable for Malaysian weather to reduce heat from the sun or provide shelter against rain, which makes it convenient for the shopper to push the shopping trolley. A food and beverage area, such as a food court, restaurant or kiosk, is a suitable place for shoppers who would like to have a short break while shopping. This will also provide benefit for shoppers who prefer to purchase readymade food after shopping. The close proximity of the food and beverage area to the 
indoor children play-land has become an attraction for parents to dine-in while waiting for the children to play.

\section{Methodology}

In order to obtain precise and relevant results, this research is conducted based on a quantitative study, with 195 data being collected through survey questionnaires from hypermarket shoppers in the city of Melaka. This data collection is based on random convenience sampling. A brief explanation on the research scope was given to all the respondents who volunteered to participate in this study. All of the respondents are regular shoppers who purchase basic grocery and household necessities at a hypermarket. The respondents were asked concerning their preference towards five additional services that are provided by the hypermarket as an extension of the basic self-service concept of the hypermarket. Each of the data that was collected was monitored by the researchers to ensure the respondents were able to understand each of the questions in the survey. With this effort, the percentage of missing data can be reduced to less than 1.5 per cent.

\section{Findings}

Based on a summary of the data that were collected, the majority of hypermarket shoppers preferred to have extended shopping services rather than just a basic self-service grocery shopping concept. The summary of respondent preferences is shown in Table 1.

Table 1. Hypermarket consumer respond on extended shopping experiences

\begin{tabular}{lll}
\hline Shopping Experience & Response & Percentage \\
\hline Banking Services & Preferred & $93.3 \%$ \\
& Not Preferred & $6.7 \%$ \\
Children Playground / Indoor Play-land & Total & $\mathbf{1 0 0 \%}$ \\
& Preferred & $66.8 \%$ \\
Covered Parking Area & Not Preferred & $33.2 \%$ \\
& Total & $\mathbf{1 0 0 \%}$ \\
Food and Beverage Area & Preferred & $88.1 \%$ \\
& Not Preferred & $11.9 \%$ \\
Post Office & Total & $\mathbf{1 0 0 \%}$ \\
& Preferred & $92.3 \%$ \\
& Not Preferred & $\mathbf{7 . 7 \%}$ \\
& Total & $\mathbf{1 0 0 \%}$ \\
& Preferred & $83.3 \%$ \\
\hline
\end{tabular}

The most preferred hypermarket service extension by the respondent is banking services, which represents $93.3 \%$. Only $6.7 \%$ of the respondents do not prefer to have banking services within the hypermarket. Another highly preferred service is a food and beverage area $(92.3 \%)$ where only $7.7 \%$ of the respondents preferred not to have it. There is also high number of respondents who preferred to have a covered parking area $(88.1 \%)$ where only $11.9 \%$ of the respondents preferred not to have it. High preference was also shown for the provision of a post office $(83.3 \%)$ where only $16.7 \%$ of the respondents preferred not to have it. The least preference is for a children's playground or indoor play-land at the hypermarket where only $66.8 \%$ of respondents preferred to have it. Although this is the lowest preference among the five additional services, it still shows that more than half of the total respondents perceived that a children's playground or indoor play-land could enhance the existing shopping experience.

\section{Recommendations}

The results of the study indicate the most preferred service extensions by hypermarkets. Thus, key emphasis should be given to banking services facilities, especially for automatic teller machines (ATM). The food and beverage area should also be emphasized. Hypermarkets should not only provide the space to sub retailers but also to maintain the cleanliness of the environment and the quality of food and beverage that are being sold. Due to the Malaysian lifestyle, which is becoming more and more sophisticated, investment in covered parking areas 
should be made to welcome more shoppers. Post offices could also be emphasized since there are many transactions that can be made through this hub. The last emphasis on service extension should be on a children's playground or indoor play-land to attract a group or family to come and shop together at the hypermarket.

Shopping for groceries is a low involvement activity. Thus, there is an opportunity for retailers to spice up the shopping experience with more positive feelings (De Wulf, Odekerken-Schroder, Goedertier and Ossel, 2005). Management and marketers have to find ways to discover consumers' needs in shopping environments to enhance the satisfaction, and encourage repeat visits and positive word of mouth. Management should also look into elements that could provide extra attraction to shoppers through experience, entertainment, excitement and social gathering rather than just a simple bargain (Ahmed et al., 2007). This research focused on hypermarket consumers in the city of Melaka. The study could be enhanced further by looking into a wider geographical scope within Malaysia as well as in other countries. This is due to shopping cultures not being fixed across countries (Millan and Howard, 2007).

\section{Conclusion}

In line with the transformation of the hypermarket retailing revolution, the basic self-service concept for grocery shopping at hypermarkets should be taken to another level of innovation (Hassan and Rahman, 2012). Hypermarket shoppers require more than just the purchase of basic necessities and groceries for the household. The pressure of urban lifestyle has influenced the hypermarket retailers to change the basic concept to be more relevant with current needs. The failure of a particular hypermarket outlet to meet this extended expectation will encourage shoppers to shift to other hypermarket outlets that are able to cater to their preferences.

\section{Acknowledgements}

This research project has been supported by the Multimedia University, Malaysia through an internal research grant. Special appreciation is given to Research Management Centre of the university for approving this research project under the Mini Fund Research Cycle 1/2012 (Project ID: IP20120511014).

\section{References}

Ahmed, Z. U., Ghingold, M., \& Dahari, Z. (2007). Malaysian shopping mall behaviour: an exploratory study. Asia Pacific Journal of Marketing and Logistics, 19(4), 331-348. http://dx.doi.org/10.1108/13555850710827841

Arnold, S. J., \& Luthra, M. N. (2000). Market entry effects of large format retailers: a stakeholder analysis. International Journal of Retail \& Distribution Management, 28(4-5), 139-154. http://dx.doi.org/10.1108/09590550010319896

Aylott, R., \& Mitchell, V. W. (1999). An exploratory study of grocery shopping stressors. British Food Journal, 101(9), 683-700. http://dx.doi.org/10.1108/00070709910288883

Babin, B., Darden, W., \& Griffin, M. (1994). Work and/or fun: measuring hedonic and utilitarian shopping value. Journal of Consumer Research, 20(4), 644-656. http://dx.doi.org/10.1086/209376

Bjurklo, M., Edvardsson, B., \& Gebauer, H. (2009). The role of competence in initiating the transition from

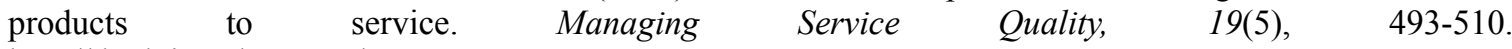
http://dx.doi.org/10.1108/09604520910984346

Bloch, P. H., Ridgway, N. M., \& Dawson, S. A. (1994). The Shopping Mall as Consumer Habitat. Journal of Retailing, 70(1), 23-42. http://dx.doi.org/10.1016/0022-4359(94)90026-4

Boedeker, M. (1995). Optimum stimulation level and recreational shopping tendency. European Advances in Consumer Research, 2, 372-380.

Bolton, R., Grewal, D., \& Levy, M. (2007). Six strategies for competing through service: An agenda for future research. Journal of Retailing, 83(1), 1-4. http://dx.doi.org/10.1016/j.jretai.2006.11.001

Bristol, T. (2002). Potential points of brand leverage: consumers' emergent attributes. Journal of Product and Brand Management, 11(4), 198-212. http://dx.doi.org/10.1108/10610420210435416

Brown, B., Sichtmann, C., \& Musante, M. (2011). A model of product-to-service brand extension success factors in B2B buying contexts. Journal of Business \& Industrial Marketing, 26(3), 202-210. http://dx.doi.org/10.1108/08858621111115921

Burt, S. (2000). The strategic role of retail brands in British grocery retailing. European Journal of Marketing, 34(8), 875-890. http://dx.doi.org/10.1108/03090560010331351

Chetthamrongchai, P., \& Davies, G. (2000). Segmenting the market for food shoppers using attitudes to shopping and to time. British Food Journal, 102(2), 81-101. http://dx.doi.org/10.1108/00070700010313071 
Clarke, I., Hallsworth, A., Jackson, P., Kervenoael, R., Aguila, R. P., \& Kirkup, M. (2004). Retail competition and consumer choice: contextualizing the "food deserts" debate. International Journal of Retail \& Distribution Management, 32(2), 89-99. http://dx.doi.org/10.1108/09590550410521761

De Wulf, K., Odekerken-Schroder, G., Goedertier, F., \& Ossel, G. V. (2005). Consumer perceptions of store brands versus national brands. Journal of Consumer Marketing, 22(4), 223-232. http://dx.doi.org/10.1108/07363760510605335

Dennis, C., Jayawardhena, C., Wright, L. T., \& King, T. (2007). A commentary on social and experiential (e-)retailing and (e-)shopping deserts. International Journal of Retail \& Distribution Management, 35(6), 443-456. http://dx.doi.org/10.1108/09590550710750322

Dennis, C., Marsland, D., \& Cockett, T. (2001). Data mining for shopping centres-customer knowledge-management framework. Journal of Knowledge Management, 5(4), 368-374. http://dx.doi.org/10.1108/13673270110411797

Dholakia, R. R. (1999). Going shopping: key determinants of shopping behaviours and motivations. International Journal of Retail and Distribution Management, 27(4), 154-165. http://dx.doi.org/10.1108/09590559910268499

Fiore, A. M., \& Kim, J. (2007). An integrative framework capturing experiential and utilitarian shopping experience. International Journal of Retail and Distribution Management, 35(6), 421-442. http://dx.doi.org/10.1108/09590550710750313

Guy, F. (2003). High-involvement work practices and employee bargaining power. Employee Relations, 25(5), 453-469. http://dx.doi.org/10.1108/01425450310490165

Hare, C. (2003). The food-shopping experience: a satisfaction survey of older Scottish consumers. International Journal of Retail \& Distribution Management, 31(5), 244-255. http://dx.doi.org/10.1108/09590550310472415

Hart, C., \& Davies, M. (1996). The location and merchandising of non-food in supermarkets. International Journal of Retail \& Distribution Management, 24(3), 17-25. http://dx.doi.org/10.1108/09590559610147892

Hassan, H., \& Rahman, M. S. (2012). Corporate Brand Extensions as an Innovation for Hypermarket Brand Momentum. International Journal on Social Science, Economics and Art, 2(1), 26-30.

Howard, E. (1993). Assessing the impact of shopping centre development: the Meadowhall case. Journal of Property Research, 10, 97-119. http://dx.doi.org/10.1080/09599919308724084

Howard, E. (2007). New shopping centres: is leisure the answer? International Journal of Retail \& Distribution Management, 35(8), 661-672. http://dx.doi.org/10.1108/09590550710758649

Hutchison, N., Adair, A., \& McWilliam, J. (2008). Covenant strength in shopping centres: a diversified risk? $\begin{array}{llll}\text { Journal of Property Investment and } & \text { Finance, 26(4), 341. }\end{array}$ http://dx.doi.org/10.1108/14635780810886636

Kaufman, C. (1996). A new look at one stop shopping: a TIMES model approach to matching store hours and shopping schedules. Journal of Consumer Marketing, 13(1), 4-25. http://dx.doi.org/10.1108/07363769610147848

Kent, T. (2003). 2D23D: Management and design perspectives on retail branding. International Journal of Retail and Distribution Management, 31(3), 131-142. http://dx.doi.org/10.1108/09590550310465503

Kirkup, M., Kervenoael, R. D., Hallsworth, A., Clarke, I., Jackson, P., \& Aguila, R. P. (2004). Inequalities in retail choice: exploring consumer experiences in suburban neighborhoods. International Journal of Retail \& Distribution Management, 32(11), 511-522. http://dx.doi.org/10.1108/09590550410564746

Kumar, P. (2005). The competitive impact of service process improvement: Examining customers' waiting experience in retail markets. Journal of Retailing, 81, 171-180. http://dx.doi.org/10.1016/j.jretai.2005.07.002

Lee, M. (1995). Going grey. Asia Magazine, 18-20, 8-11.

Lee, M., \& Ulgado, F. M. (1993). Service extension strategy: a viable basis for growth? Journal of Service Marketing, 7(2), 24-35. http://dx.doi.org/10.1108/08876049310038382

Liao, S. H., Chen, C. M., \& Wu, C. H. (2008). Mining customer knowledge for product line and brand extension in retailing. Expert Systems with Application, 34, 1763-1776. http://dx.doi.org/10.1016/j.eswa.2007.01.036

Martin, C. R. (1996). Retail service innovations: input for success. Journal of Retailing and Consumer Services, 3(2), 63-71. http://dx.doi.org/10.1016/0969-6989(95)00054-2 
Martinez-Ruiz, M. P., Jimenez-Zarco, A. I., \& Cascio, R. (2011). Assessing the maximum level of customer satisfaction in grocery stores; A comparison between Spain and the USA. International Journal of Retail \& Distribution Management, 39(7), 504-521. http://dx.doi.org/10.1108/09590551111144897

Mascarenhas, O. A., Kesavan, R., \& Bernacchi, M. (2004). Customer value-chain involvement for co-creating customer delight. Journal of Consumer Marketing, 21(7), 486-496. http://dx.doi.org/10.1108/07363760410568707

Millan, E. S. \& Howard, E. (2007). Shopping for pleasure? Shopping experiences of Hungarian consumers. International Journal of Retail \& Distribution Management, 35(6), 474-487. http://dx.doi.org/10.1108/09590550710750340

Mintel. (2000). Grocery E-tailing. Mintel, London.

Mishra, D. P. (2000). Interdisciplinary contributions in retail service delivery: review and future directions. Journal of Retailing and Consumer Services, 7, 101-118. http://dx.doi.org/10.1016/S0969-6989(99)00008-9

Pecotich, A., Pressley, M., \& Roth, D. (1996). The impact of country of origin in the retail service context. Journal of Retailing and Consumer Services, 3(4), 213-224. http://dx.doi.org/10.1016/0969-6989(95)00080-1

Ramus, K., \& Nielsen, N. A. (2005). Online grocery retailing: what do consumers think? Internet Research, 15(3), 335-352. http://dx.doi.org/10.1108/10662240510602726

Roy, D. P. (2010). The impact of congruence in cause marketing campaign for service firms. Journal of Service Marketing, 24(3), 255-263. http://dx.doi.org/10.1108/08876041011040659

Salmon, W. J., Buzzell, R. D., \& Cort, S. G. (2000). Today the shopping center, tomorrow the superstore. Harvard Business Review.

Seiders, K., \& Tigert, D. J. (2000). The impact of supercenters on traditional food retailers in four markets. International Journal of Retail \& Distribution Management, 28(4-5), 181-193. http://dx.doi.org/10.1108/09590550010319931

Shannon, R., \& Mandhachitara, R. (2008). Causal path modeling of grocery shopping in hypermarkets. Journal of Product \& Brand Management, 17(5), 327-340. http://dx.doi.org/10.1108/10610420810896086

Sit, J., Merrilees, B., \& Birch, D. (2003). Entertainment-seeking shopping centre patrons: the missing segments. International Journal of Retail and Distribution Management, 31(2), 80-94. http://dx.doi.org/10.1108/09590550310461985

Soars, B. (2003). What every retailer should know about the way into the shopper's head. International Journal of Retail \& Distribution Management, 31(12), 628-637. http://dx.doi.org/10.1108/09590550310507759

Solomon, B. (1994). TV shopping comes of age. Management Review, 83(9), 22-26.

Stoltman, J. J., Morgan, F. W., \& Anglin, L. K. (1999). An investigation of retail shopping situations. International Journal of Retail and Distribution Management, 27(4), 145-153. http://dx.doi.org/10.1108/09590559910268453

Stone, G. P. (1954). City shoppers and urban identification: Observation on the social psychology of city life. American Journal of Sociology, 60, 36-45. http://dx.doi.org/10.1086/221483

Sun, P. C. (2010). Differentiating high involved product by trivial attributes for product line extension strategy. European Journal of Marketing, 44(11-12), 1557-1575. http://dx.doi.org/10.1108/03090561011079792

Swoboda, B., Haelsig, F., Morschett, D., \& Schramm-Klein, H. (2007). An intersector analysis of the relevance of service in building a strong retail brand. Managing Service Quality, 17(4), 428-448. http://dx.doi.org/10.1108/09604520710760553

Swoboda, B., Haelsig, F., Schramm-Klein, H., \& Morschett, D. (2009). Moderating role of involvement in building a retail brand. International Journal of Retail and Distribution Management, 37(11), 952-974. http://dx.doi.org/10.1108/09590550910999370

Tauber, E. M. (1972). Why do People Shop? Journal of Marketing, 36, 46-49. http://dx.doi.org/10.2307/1250426

Thomas, A., \& Garland, R. (2004). Grocery shopping: list and non-list usage. Marketing Intelligence and Planning, 22(6), 623-635. http://dx.doi.org/10.1108/02634500410559015

Viot, C. (2011). Can brand identity predict brand extensions' success or failure? Journal of Product \& Brand Management, 20(3), 216-227. http://dx.doi.org/10.1108/10610421111134941

Wagner, T. (2007). Shopping motivation revised: a means-end chain analytical perspective. International Journal of Retail \& Distribution Management, 35(7), 569-582. http://dx.doi.org/10.1108/09590550710755949 